\title{
Market versus Internal Factors in Corporate Governance
}

\section{Praveen Kumar \& Alessandro Zattoni}

There is a long-standing distinction in the corporate governance literature between market and internal factors that drive firm performance. In their seminal formulation of the separation between ownership and control, Berle and Means (1932) were skeptical of both internal institutions (such as boards) and outside shareholder pressure as effective means to monitor powerful managers. Starting in the 1960s, building especially on the influential work of Manne (1965), the focus of many scholars, at least in the U.S. and U.K., turned to the disciplining role of financial markets implemented through an active market for corporate control (Shleifer \& Vishny, 1986). In essence, while powerful managers may be invulnerable against internal mechanisms and shareholder proxy motions, market actors (in the form of large shareholders, competing firms, etc.) would target underperforming firms for acquisitions and displace inefficient incumbent management. More generally, financial markets can discipline self-serving and underperforming managers or controlling shareholders through low equity and debt valuations (e.g., Claessens, Djankov, \& Lang, 2000; Aslan \& Kumar, 2012, 2014) that expose them to takeover threats. This view finds its broad culmination in the influential law and finance literature (La Porta. Lopez-de-Silanes, Shleifer \& Vishny, 1997), which emphasizes strong investor rights as the central determinant of corporate governance performance.

It is noteworthy that the market discipline perspective tends to view market and internal institutional factors in corporate governance as substitutes (see, e.g, Cyert, Kang, \& Kumar 2002), whereby market pressure offsets weak internal governance mechanisms and related institutions. However, there is now a substantial literature that theoretically and empirically shows that the market for corporate control may not unambiguously be a substitute for weak internal governance. In practice, there is a complex interaction between market and internal mechanisms, especially in international contexts (Kumar \& Zattoni, 2014; Schiehll, Ahmadjian, \& Filatochev, 2014). For example, the external market pressures can interact with internal mechanisms as both substitutes and complements, which is seen in the complex determinants of board performance (Kumar \& Zattoni, 2013a). And the effectiveness of market discipline for good governance is mediated substantially by country-level variables (Kumar \& Zattoni, 2013b). Furthermore, the fact that bidders typically do not gain from acquisitions (Jensen \& Ruback, 
1983) is consistent with the view that powerful managers may pursue value-destroying acquisitions. Similarly, the implications of concentrated ownership, such as in family firms, for firm performance in innovation are subtle (Lodh, Nandy, \& Chen, 2014).

In this issue, four papers significantly expand our understanding of the multi-dimensional interaction between market forces and internal factors in corporate governance. The included studies use sound, and sometimes novel, theoretical frameworks on interesting international data to rigorously generate a number of interesting insights.

The first paper, by McCann and Ackrill, presents a novel perspective on the interaction between the market for corporate control and the board. These authors pose an intriguing question: Do internal institutions get stronger following acquisition bids that are abandoned? In particular, do weak boards who may not have the power to confront or monitor entrenched managers before the acquisition bid become emboldened to confront management following the failure of the bid? Hence, interestingly, the likelihood of post-abandonment may be higher with weak boards. In this case, the external market forces and internal governance mechanisms would have a complementary and not substitute relationship. Surprisingly, this issue, which appears to be of significant importance to the understanding of internal corporate governance dynamics, has been essentially unexplored in the literature. And even the few studies that have studied this issue tend to use narrow measures of post-abandonment performance. The paper goes further and asks whether boards use the information content in negative price responses to bids, acquisition attempts on unrelated targets, and the use of cash (which is of strategic value to firms, and hence reflects value-destroying bids) to strengthen their position vis-à-vis powerful CEOs. The study uses U.K. data on abandoned bids, firm-level data on board independence, market data on price response to bids, and transactions data on the cash proportion of the bid. The results support the overall hypothesis that in the case of abandoned bids, internal governance mechanisms and the market for corporate control act in a complementary and not substitute fashion. The analytic structure of the paper is truly inter-disciplinary, integrating aspects of finance, corporate governance, institutional structure, and strategic management.

The second paper, by Kavadis and Kastner, also explores the interplay between financial markets and internal factors. The globalization and integration of financial markets in the last two decades have led to significant pressures for restructuring, usually instigated by institutional 
investors. Since most of these investors are based in the U.S. and UK, this has led to two types of conjectures in the literature (Cuomo, Zattoni \& Valentini, 2013). One view holds that the globalization of financial markets will accelerate the convergence of corporate governance of international firms to Anglo-American standards that emphasize value-creation and dilution of internal control (Kumar \& Ramchand, 2008). The other view holds that firms outside the AngloAmerican world, especially family firms, will resist pressures from the global financial investors, that is, the interaction between local owners and international investors will be tacitly or explicitly confrontational (Gomez-Mejia et al., 2011). The Kavadis and Kastner study shows that the reality is more complex and subtle. Using longitudinal data from French public firms during a period when there was a major increase in ownership by Anglo-American institutional investors, Kavadis and Kastner find that approaches toward corporate restructuring are determined by interaction and co-existence between different types of owners, who typically have different value systems. In particular, their careful analysis presents results that are in contrast to the rather simplistic expectations of anti-restructuring local owners versus prorestructuring Anglo-American investors. The authors find that family ownership is positively related to restructuring. Furthermore, Anglo-American institutional investors ownership generally has no significant effect on the likelihood of restructuring; however, high levels of ownership by these players are conducive to restructuring. An especially interesting result is that the attitude of French family owners towards restructuring is influenced by firm performance relative to their aspiration levels (Cyert \& March, 1963). The lower the performance relative to aspiration levels, the more open are French owners to restructuring. Overall, the paper is a very interesting study of the interplay between diverse owners with different value systems with respect to restructuring and management. It also shows how value-maximizing and non-valuemaximizing approaches to firm management co-exist in international environments.

The third study, by Jin and Park, examines the implications of the separation between cash flow and control ownership for firm performance in large business groups in South Korea. As we mentioned already, the negative consequences of such separation have been emphasized in the literature. However, as Jin and Park point out, there is a literature that recognizes that the deviation between cash flow and control ownership may occur because of well-functioning internal capital markets. In particular, firms within large business groups are tied together by formal and informal networks, and attempt to offset frictions in external financing through 
internal capital markets. The deviation between cash flow and control ownership can occur when these group member firms make equity investments in affiliated firms. In such situations, the standard agency-theoretic argument for the negative effects of the cash flow-control rights separation need not hold. In fact, if the internal financing efficiency benefits exceed agency costs, then separation (up-to a point) may be positively related to performance. Somewhat surprisingly, this possibility has not been examined empirically in natural settings such as those considered by Jin and Park. Their study indeed finds that the separation between cash flow and control rights is positively related to accounting performance, but not to market performance. This finding is consistent with global investors viewing the cash flow-control separation with suspicion or as a "rule of thumb." The study also shows that the effects of separation are moderated by macroeconomic and firm-level factors relating to the benefits of internal financing and severity of agency costs. Given the specific context of the sample firms, namely affiliation with large business groups, the study does not suggest that separation of cash flow and control is generally beneficial. Rather it suggests that the relation of ownership structure to corporate governance and firm performance may depend on the financial and institutional context, which is an important contribution to a long-studied question.

The fourth study, by Jain and Shao, examines the effects of ownership structure (family versus non-family ownership) on the post-IPO financing of newly public firms. It is well known that investment financing needs and lower agency or information-production costs are important drivers of going public (Aslan \& Kumar, 2011; Zattoni \& Judge, 2012). However, there is substantial diversity in the post-IPO financing choices. In particular, many newly public firms do not raise capital from public capital markets. Jain and Shao posit that family ownership may be an important factor in this behavior. Compared with non-family public firms, the agency conflicts in family firms are distinct. Family firms have less managerial-owner conflicts than other public firms, but also have higher agency conflicts with minority shareholders. Moreover, family firms have a focus on maintaining socioeconomic wealth and long run survival. Building on these observations, the authors hypothesize that post-IPO family firms will be more conservative in equity financing and issue debt of longer maturity, compared with the other public firm. Of course, these financial strategies also would impose financial constraints on family firms, leading to higher investment sensitivity to cash flows. Using U.S. data, Jain and Shao find empirical results consistent with these hypotheses. 


\section{References}

Aslan, H. \& P. Kumar, 2011, Lemons or cherries? Growth opportunities and market temptations in going public and private. Journal of Financial and Quantitative Analysis, 46: 486-526.

Aslan, H. \& P. Kumar, 2012, Strategic ownership structure and the cost of debt. Review of Financial Studies, 25: 2257-2299.

Aslan, H., Kumar, P. 2014. National governance bundles and agency costs: A cross-country analysis. Corporate Governance: An International Review, 22: 230-251.

Claessens, S., Djankov, S., \& Lang, L. 2000. The separation of ownership and control in East Asian corporations. Journal of Financial Economics, 58: 81-112.

Cuomo, F., Zattoni, A., and Valentini, G., 2013. “The effects of legal reforms on the ownership structure of listed companies”, Industrial and Corporate Change, 22(2): 427-458.

Cyert, R. M. \& March, J. G. 1963. A behavioral theory of the firm. Englewood Cliffs, NJ: Prentice-Hall.

Cyert, R., Kang, S., \& Kumar, P. 2002. Corporate governance, take-overs, and top management compensation: Theory and evidence. Management Science, 48: 453-469.

Gómez-Mejia, L. R., Cruz, C., Berrone, P., \& de Castro, J. 2011. The bind that ties: Socioemotional wealth preservation in family firms. Academy of Management Annals,5: 653707.

Kumar, P. \& Ramchand, L. 2008. Takeovers, market monitoring, and international corporate governance. Rand Journal of Economics, 39, 850-874.

Kumar, P., Zattoni, A. 2013a. Corporate governance, board of directors, and firm performance. Corporate Governance: An International Review, 21: 311-313.

Kumar, P., Zattoni, A. 2013b. How much do country-level or firm-level variables matter in corporate governance studies? Corporate Governance: An International Review, 21: 199-200a

Kumar, P., Zattoni, A. 2014. Corporate Governance, Information, and Investor Confidence. Corporate Governance: An International Review, 22: 437-439.

La Porta, R., Lopez-de-Silanes, F., Shleifer, A., \& Vishny, R. 1998. Law and finance. Journal of Political Economy, 106: 1113-1155.

Lodh, S., Nandy, M., \& J. Chen, 2014. Innovation and family ownership: Empirical evidence from India. Corporate Governance: An International Review, 22: 4-23. 
Manne, H. G. 1965. Mergers and the market for corporate control. Journal of Political Economy,73: 110-120.

Schiehll, E., Ahmadjian, C., Filatotchev, I. 2014. National Governance Bundles Perspective: Understanding the Diversity of Corporate Governance Practices at the Firm and Country Levels. Corporate Governance: An International Review, 22: 179-184.

Shleifer, A. \& Vishny, R. 1986. Large shareholders and corporate control. Journal of Political Economy, 94: 461-488

Zattoni, A. and Judge, W. (eds.), 2012. Corporate Governance and Initial Public Offerings: An International Perspective, Cambridge University Press, Cambridge. 